\title{
Remittances and Poverty Reduction in Somalia
}

\section{Erol BULUT ${ }^{1}$, Abdiqadar Abdignani MOHAMED ${ }^{2}$}

\begin{tabular}{l} 
ARTICLE INFO \\
\hline Article History: \\
Date Submitted: 09.06.2018 \\
Date Accepted: 09.07.2018 \\
\hline JEL Classification: \\
J24 \\
I32 \\
O55 \\
J60
\end{tabular}

Keywords:

Remittances,

Poverty Headcount Raito,

Poverty Gap,

Poverty Severity

\begin{abstract}
The flow of remittances to Somalia makes $23 \%$ of the whole GDP of Somalia. It means that remittances contribute to the Somali GDP more than Foreign Aid (FA) Official Developmental Assistants (ODA) and also the Foreign Direct Investment (FDI) do. That shows how crucial remittances are for the people of Somalia as an external source of financing. Therefore, remittances play a key role in decreasing the extreme poverty and increasing the social development as well. That is because of the increase of the income of the Somali families receiving remittances. As families receive remittances it makes possible for them to meet their basic needs and requirements in life. Remittances also play a crucial role in employment and creating more jobs for the Somalis back home. Somali Diaspora living abroad also bring new skills, opportunities and profitable business ideas back home and that slowly but surely stimulates the employments and increases the incomes of the families living back home, Somalia.

This study will analyze the correlation between remittances and poverty in Somalia. The data which is going to be used is that of secondary data from surveys made by World Bank which is called Somali High Frequency Survey (SHFS), International Monetary Fund (IMF) and UNICEF. The relations between remittances and poverty headcount ratio is not significantly supported by the case of Somalia. Therefore, remittances in Somalia has no a tangible impact on poverty headcount ratio in Somalia. But when it comes to the poverty gap and the poverty severity in the regions of Somalia, it seems that remittance has an active role in reducing both of them more than it does in the poverty headcount ratio in Somalia. Also there is no a significant relation between remittances and the inequality among Somalis.
\end{abstract}

\footnotetext{
${ }^{1}$ Doç. Dr. Öğr. Üyesi, Hacı Bayram Veli Üniversitesi İİBF İktisat Bölümü, erolbulut@gmail.com

${ }^{2}$ Mogadishu University
} 


\section{Introduction}

Migration refers to as the process in which people move from one location or country to another. A person migrates from his home country or region to another region or country, expecting to benefit economically and decides to move rather than staying. There are more than 215 million migrant people worldwide and the recorded remittance flow was estimated to be US\$440 billion in 2010 as the World Bank data shows. From 1990, starting from the beginning of the 21 st century, remittances are increasing continuously, even during the period of the economic crisis of 2009. There is very tangible and crucial impact of remittances on the development of the countries receiving remittances but there is a limited research focusing on this sector, the remittance industry (World Bank, 2011).

There are two views regarding the effect of remittance on the development of the countries receiving it. One view is an optimistic while the other is a pessimistic view. In the optimistic view, migration reduces poverty as people migrate from low-income rural areas to high-income urban areas or from low income to high income countries. The increase in income is a result from the increase in remittances leading to a decrease in poverty. Migrants also learn and acquire new skills and obtain business ideas from abroad, so migrants' remittances become beneficial for the development of developing countries. On the other hand, pessimistic thought argues that it is not the poor people but the richer or skilled and educated people who can migrate to high wage-earning locations or countries. As people migrate to a new country they start working hard to settle and integrate within the new society but disregard or forget their birth country. So that, migration creates brain drain and also remittance inflow makes the economy more dependent, increases inflation and causes an exchange rate appreciation (Devkota, 2015).

The migrant workers in foreign countries send remittances back home. These remittances have a profound impact on the living standards of the people in the countries of origin such as countries in Africa, Asia and Latin America. In recent years, the economic impact of remittances on poverty in under developed and developing countries have attracted the attention of policy makers and researchers around the world. 
Remittances are sent by migrant workers in abroad directly adds to the normal family income which the family to meet and fulfil their needs. Remittances are also can be sent by individuals or communities living and working in abroad to the communities back home for education and health services, humanitarian assistants and relief operations. Social Remittances consists of the business ideas and skills acquired and obtained by the migrant workers learning from the communities in host countries. They come back and bring those ideas to their home countries. In that way they create jobs and reduce poverty in the country of origin (Devkota, 2015).

After the collapse of the central government in 1991 all the governmental institutions were destroyed and even looted by the people of Somalia. Civil war severely damaged the life of the civilians. Education, healthy and all the other basic needs disappeared. Lots of people lost their precious lives for no reason. Poverty and hunger become normal among the people of Somalia. Deadly diseases started to spread across the country. People started fleeing from their mother land and dying in the deadly deserts and also in the rough oceans and seas looking for better lives.

The people of Somalia migrated from their country of origin to around the world such as the neighboring countries, North America and Europe seeking better life for themselves and for their families back home as well. Fortunately, Those Somalis who migrated abroad started to work there and send money back home and help other relative members migrate and also work abroad. Therefore, Somali migrant workers working abroad become significant for the Somali economy as they sent money back home, increase the income levels of the families in Somalia and as a result reduce the poverty levels of the people in Somalia. Remittances to Somali family members in the country are a well-established practice.

Remittance flows were estimated at up to $\$ 1$ billion in 2004 but could be as high as $\$ 1.6$ billion to Somalia and $\$ 700$ million to Somaliland, the self-declared independent semiautonomous region in Northern Somalia. Remittances represent $23 \%$ of household income with up to $40 \%$ of households receiving some assistance (Lindley, 2007). 
This study is going to analyze the impact of remittances on poverty in Somalia. Secondary data from the World Bank is used. The World Bank applied the first wave of the Somali High Frequency Survey in 2016. The survey was managed to 4,117 households distributed among rural and urban areas, and IDP settlements. The geographical coverage has been improved to most regions in Somalia. However, the sample still is not fully representative of the Somali population as it excludes nomadic households and households in insecure areas.

A sample regression is used to analyze the data and what is found is that remittances have a negative impact on poverty headcount ratio, poverty severity, poverty gap and inequality but a positive correlation with the small family business across the selected regions in Somalia. Nevertheless, remittances have a significant negative correlation with the poverty severity more than with poverty gap and poverty headcount ratio.

\section{Theories and the Literature Review of Migration, Remittances and Poverty}

Due to globalization and economic interdependency, people migrate from poor countries or regions to well-paid regions or countries. So migration become normal and a worldwide phenomenon which is practiced by so many people around the world. In recent decades, people who are migrating and the flow of remittances is increasing in number. Therefore, policy makers, researchers and development act maniacs are paying a greater attention and concern whether or not remittances have a positive impact on poverty alleviation and development or not. This section is going to analyze the existing theories regarding migration, remittances and the empirical findings related to the impacts of remittances on poverty, inequality and investment.

\subsection{Reasons Behind International Migration: Theoretical Background}

A comprehensive review on theories of international migration was done by Massy et al. (1993). A low equilibrium wage rate and less capital are found in countries which have excess labor force, whereas countries with less labor force have a higher equilibrium wage rate and more capital as the neo-classical macroeconomic theory argues. Therefore, the main reason for international migration is due to the incomes difference between those countries. 
The destination countries' wage rates decrease due to immigrants' inflow, while in the country of origin wages increase due to international labor outflow and then a new equilibrium wage rate will be established in both countries of origin and destination after migration takes place. Geographical structure is also another factor which may affect and influence migration. For that reason, wage differential, labor surplus or deficiency, and geographical structures are the major factors for international migration. Highly skilled labor migration is quite different from the migration of low-skilled workers (Devkota, 2015). Costs (travel cost, new job search cost, new language learning and cultural adjustment cost, joining a new labor market cost and other psychological costs) and benefits (high wages and other returns) of international migration based on their skills are also to be calculated by migrants before they do so to migrate as the neo-classical microeconomic theory views the case. Another determinant factor of migration is that of the employment rate in the destination country. International migration can also be stimulated by the human capital characteristics such as education, experience, training, and language skills. Migration also increases when domestic social or economic conditions, such as capital and technical availability, are low in the country of origin. In addition, the scale of migration is determined and controlled by the size of expected returns after migration. Other markets control migration weather to be increased or decreased. Governments can control, intervene or regulate the labor market. That means employers and laborers have a complete awareness and knowledge about the wage rates of different countries (Devkota, 2015).

Taylor (1999) suggested the New Economics of Labor Migration (NELM) theory and suggested a different view on the determinants of migration. It is not only the individual laborer but the household makes migration decisions as the author argued. At the household level migration research can be done better than in individual unit. People migrate for risk diversification so that wage differences are not the only necessary condition of migration. Improving the living conditions within the given context (number of family members, amount of land and others) is the objective of every household. Aggregate returns are maximized and risk minimized as some family members work in the local community while some practice international migration. Government benefits are insignificant or nil in developing countries. Although in developed countries, the unexpected economic issues of the households such as health problem or diseases that affect agricultural products are mitigated by governments 
through insurance. Therefore, in times of crisis migrants send remittances to support other family members. The stage of domestic development and international migration are not two issues which are independent each other but instead of that, they are two interdependent things. Migration abroad can also be simply influenced by an increase in the rate of return in the home country. Mobility costs and the worker's age also contribute to migration decisions. If other markets in the home country are imperfect, migration will continue and even start to increase. Insurance markets, capital markets and so on can be used by the government to influence migration. Migration can also be affected by unemployment benefits and income distribution policy (Devkota, 2015).

The main reason for international migration is that of demand-based industrial growth in developed economies as the dual market theory advocates. In order to keep the equilibrium constant, the employer needs to recruit new workers so that the existing wage rate does not increase and the profit levels do not decrease. Immigrants cannot bargain for higher wage rates as they are in lower positions due to institutional and policy parries. Societies have no such significant role in influencing labor demand and supply. Also there is a little governmental policy role (Devkota, 2015). International migration is the natural result of capitalism as the world systems theory also emphasizes. Capital and goods flow from developed to developing countries and labor flows in the opposite direction. Most migration is likely to flow between former colonies and colonial powers because the economic systems match. International is the result and recognized as is the consequence of globalization and the market economy. So that the government can do little to influence it (Devkota, 2015).

Network theory argues that when someone locates abroad, he/she gathers socioeconomic information about the country he came and then informs other family members or relatives about going abroad. This process minimizes migration costs and job risks in the destination country. This argument is relevant in the Nepalese context. One Nepalese used to work in an Indian restaurant in Japan. Later he became an entrepreneur, opened a restaurant on his own and called his brothers to work. Consequently, the other brothers also opened new restaurants and invited other relatives and so on. This trend also holds true in other countries (Devkota, 2015). 
Classical theory argues that migrants have adequate knowledge about the wage rates of the destination countries. This assumption is not applicable to the real world. In the recent years, man-made causes such as political instability, insecurity and environmental issues such as sea level rise, and natural disaster are also among the reasons of migration. Economic ups and downs, expanding means of transportation and internet facility are also major determinants of international migration. Moreover, new generations are interested in going to new places and learning new ideas (knowledge migration) which will be useful economically after returning to their home country contributing the GDP of the host country to be increased (Devkota, 2015).

\subsection{Remittances, Investment and Growth}

Recent research by Clemens (2011) argued that the World GDP would rise between 50 to 150 percent if the international labor movement barriers were significantly minimized. But now in some developing countries remittance inflow represent from 10 up to near 50 percent of the annual national GDP of those countries as the diagram below shows.

\section{Figure 1: Remittances Ratio in Selected Countries-2013}

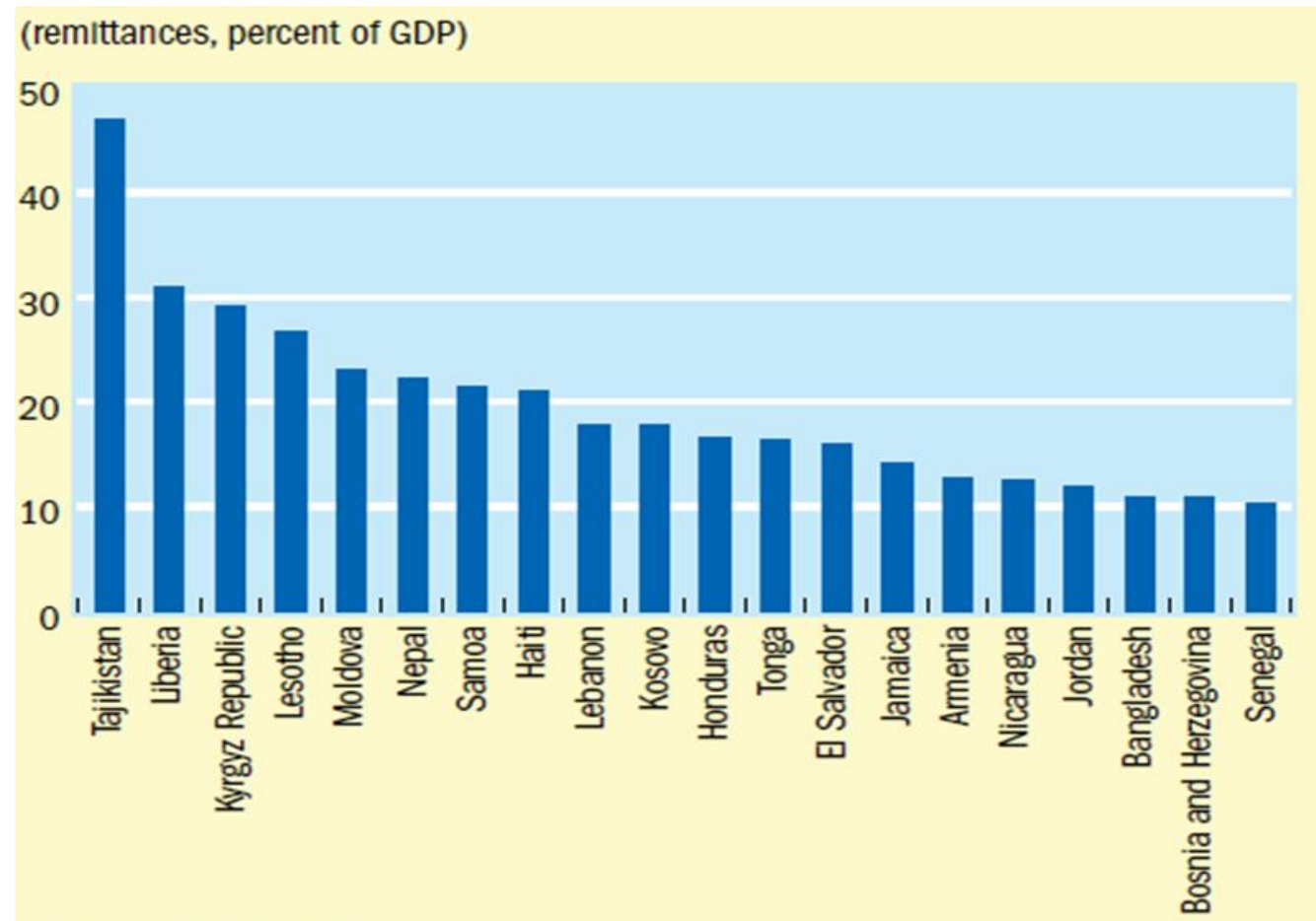

Source: World Bank, 2013. 
Remittances has a major and significant role in boosting economic development but through gradual process. As remittances increase family incomes so encourages savings, entrepreneurship, investments, creating more job opportunities and finally remittances can cause an increase in overall consumption on health and education to attain a high living standard. When remittance inflow increases, aggregate investment and growth increases so that Remittance contributes positively to development. On the other hand, Remittances are helpful for macroeconomic crises and natural disasters. At the micro level remittances contribute the family income to be increased, increased savings, consumption of durable goods, human capital development as the children are able to go to school, the health of the children and so on. Remittances will help financial sector development by increasing bank deposits and credits if it is consumed immediately. Those households receiving remittances are more likely to save and increase deposits than other households who are not receiving remittances in Haiti, Dominican Republic and Guatemala. More bank branches have been opened in large-scale remittance receiving municipalities in Mexico, and a relatively higher saving ratio exists (Fajnzylber and Lopez, 2008). When people migrate from their countries of origin to new countries, they do not simply abandon ties with their countries of origin. Instead they definitely can contribute the development of their home countries. For example, they will continue communicating with their family back home and transmit new ideas related to economic and cultural aspects from the destination countries. Migrants' diaspora can play an important role for development as the development economists argue. For example, there are more than 30 million African international migrations around the world. So that those diaspora can play a significant role in the development of the African region.

Diaspora can promote trade (migrants may prefer foods from their country of origin), direct investment (migrants know more information about market structure in his/her birth place than foreigners) and capital market development (issuing diaspora bonds). In addition to that, technology transfer and the establishment of medium- and large-scale industries is also possible through collective remittance (Plaza and Ratha, 2011). Sometimes governments might face problems with external finance but can manage money through diaspora bonds. For example, India and Israel issued diaspora bonds worth US\$40 billion. Nepal also issued a five-year foreign employment bond in 2010 targeting infrastructure development (Mohapatra et al., 2012). Hanson and Woodruff (2003), and Cox-Edwards and Ureta (2003) found 
forward linkage between remittances and human capital formation in Latin America. In conclusion, according to the recent empirical studies and the international organizations migration followed by remittances can play a significant role in the economic progress in the countries of origin. Also migration has a positive effect on the economic gains of the destination countries. Although these all benefits exist, we do not need to forget the limitations of migration, informal remittances and political influence on transnational labor migration and Brain Drain.

\subsection{Remittances and Poverty Reduction}

Poverty in its most general sense is that of insufficient or lack of necessities such as food, Shelter, clothing and so. Extreme poverty however, is the proportion of population living on less than 1.5 US \$ per day measured at purchasing power parity (PPP) for international comparisons and aggregation (World Bank, 2010). Basic food, shelter, medical care, safety, clothing are generally thought necessary based on shared values of human dignity. However, people around are different in terms of they view towards necessities and basic needs. Because what is a necessity to one person is not uniformly a necessity to others. Needs may be relative to what is possible and are based on social definition and past experience (Sen, 1999). Valentine (1968) argues that "the essence of poverty itself is inequality. The basic meaning of poverty is relative deprivation (Devkota, 2015). Mollie Orshansky, for the first time created what is called the "poverty line" in 1963 at the U.S. Department of Agriculture based on three times her estimate of what a family would have to spend for an adequate but far from lavish diet. The very definition of poverty was political, aimed to benchmark the progress of poverty programs for the War on Poverty as it is shown by Michael Darby (1997). Adjusted for inflation, it was believed that the poverty line for a family of four was $\$ 17,050$ income in 2000 according to the US Census. According to most poverty scholars identify many problems with this definition related to several concepts such as concept of family, cash income, treatment of taxes, special work related expenses and of course regional differences in the cost of living (Blank 1997; Quigley, 2003). Due to recent inflations around the world and considering the PPP (Purchasing Power Parity), the World Bank recently recognized $\$ 1.9$ as it is the updated World Poverty Line (World Bank, 2015). Therefore, $\$ 1.9$ will be the poverty line in this study. 
There is a negative relationship between migrants' remittances and poverty as most of the empirical studies have shown. Migration reduces poverty as people migrate from lowincome rural areas to high-income city areas or from low-income economies to high-income economies. Adams (2004), one of the pioneers in this field analyzed the expenditure behavior of Guatemalan households in the country level study. The study employed a two-stage selection model to correct selection bias and calculated poverty types in a counter-factual scenario sampling 7,276 households. Remittances decreased poverty both internally and externally but had more effect on the poverty gap and squared poverty gap than the poverty headcount.

In a macro level study, used 71 low- and middle-income countries' time series data and they found that both international migration and remittance reduce poverty level, poverty gap, and the severity of poverty in the developing world. A 10 percent increase in per capita official international remittances will lead to a 3.5 percent decline in the number of people living in poverty, under the poverty line. Using cross-country data of 64 developing countries, Cattaneo (2009) investigated empirically the effect of international migration on poverty in labor-sending countries and saw that a 10 percent increase in the per capita stock of migrants resident in Organization for Economic Cooperation and Development (OECD) countries augments the income of the poor by 1 percent, and 10 percent increase in expenditure per capita augments the dollar value of the poor by 3 percent on average and ceteris paribus, other things to be kept constant. Based on 33 African countries' panel data (1990-2005), Anyanwu and Erhijakpor (2010) postulated that a 10 percent increase in official international remittances as a share of GDP leads to a 2.9 percent decline in the poverty headcount. The point estimates for the poverty gap and squared poverty gap suggest that a 10 percent increase in the share of international remittances will lead to a 2.9 percent and 2.8 percent decline respectively (Adams and Page 2005).

Adams et al. (2006) also asserted that total remittances reduced poverty in Ghana applying the same methodology. The poverty gap decreased by 4.1 percent through internal remittance and also decreased about 34.8 percent through international remittances in Ghana. Distance to railroad stations, the level of rainfall and unexpected rainfall were used as instrumental variables, whereas a pair wise Average Treatment Effect (ATE) model was used 
to compare with a counterfactual scenario and that was a recent study by Adams and Cuecuecha (2010). They used Indonesian Family Life Survey panel data (2004 and 2007). These findings also showed that international remittances have a significant effect in poverty reduction in Indonesia. International remittances help to decrease poverty headcount by 26.7 percent, poverty gap by 55.3 percent and squared poverty gap by 69.9 percent. In Vietnam also, the impact of work and non-work migration on per capita income, per capita expenditures, poverty rate and inequality were estimated by Nguyan et al. (2011) using the same methodology as Adams and Cuecuecha did about Indonesia (Devkota, 2015)

On a micro-level, remittances provide and are the fundamental sources of income for those receiving remittances. While there is no visible impact of remittances on income gap between developed and developing economies, still they directly contribute to economic growth and development of local communities providing a much needed economic stability. Rural households who benefit remittances as a livelihood, approximately one third of the total remittances reinvest almost every dollar received to serve basic needs like food, medicines and clothing (Adams, 2006 and UN News Center, 2007). These aspects of basic needs which are important for the life are ingredients of poverty when people struggle to satisfy them first. The multiplier effect, the size of the multiplier depends upon household's marginal decisions to spend, is that at its maximum effect when people send remittances back home, those remittances affect the existing economy as a flow of income from outside of the existing system of incomes and circulation of money. That flow of remittances can cause marginal propensity to increase as incomes increase and investments increase as saving increases. Thus, it would be fully profited from the social returns of these investments. Once basic needs are served, remittances amounts will be spent in education which, on the long-term, will bring positive effects to local economies. Richer households will use remittances for entrepreneurship purposes because they do not need to worry about the basic needs. Therefore, they bring about social benefits in most circumstances and creating jobs for the local communities. The receiving country and its local population's propensity to save or invest and the willingness of the people are the determinants of how far is the impact of remittances on the economy. According to the International Fund for Agricultural Development (IFAD), 10-20 per cent of the amount received as a remittance is saved at home, creating a missed opportunity for local growth (IFAD, 2007). As Benabou (1996) suggests 
that providing health service opportunities, education and so on for the poor households. In fact in this context remittances, substituting for the foreign direct investments or foreign aid based redistribution schemes, may be viewed as direct transfer. In that way Community Remittances are more likely to increase human development in poor countries. This hypothesis is convenient to the extent that remittances increase growth and investment and savings rates in economies that have significant inequality, poverty and where transfers do appear to reach the poor $20 \%$ or $40 \%$ of the population (Kibikyo and Omar, 2009). As it has been seen in different researches made, remittances have a direct impact on the reduction of poverty and also have a significant positive role on health, education and gender equality (EU, 2013). As the chart below explains Remittances account for over a third of the reduction in poverty and are especially important for those in extreme poverty.

\section{Figure 2: Remittances Account for Over a Third of the Reduction in Poverty-2013}

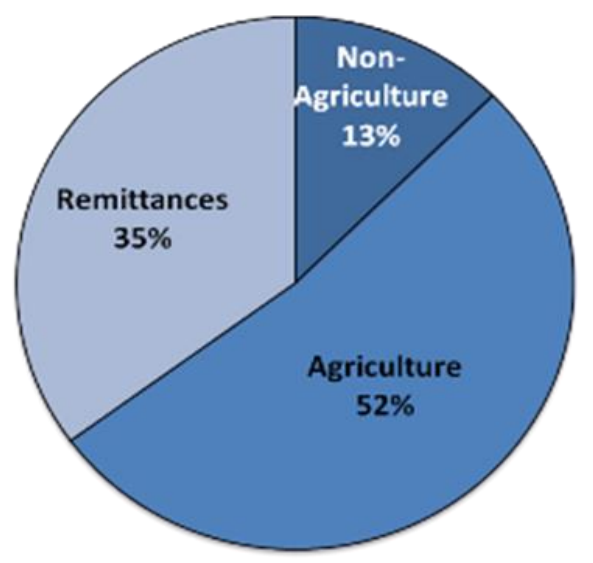

\section{Source: World Bank}

Note: Based on analysis of Brazil, Cameroon, Chile, China, Costa Rica, Dominican Republic, Egypt, Gambia, Ghana, Guatemala, Honduras, Indonesia, Kenya, Malaysia, Mali, Mauritania, Mexico, Nicaragua, Panama, Philippines, Senegal, Tajikistan, Thailand, Tunisia and Vietnam.

The analysis of poverty impact of remittances must account for counter-factual loss of income that the migrant may experience due to migration, if the migrant has to give up her/his initial job at the home country. Such losses are likely to be small for the poor and unemployed, but large for the middle- and the upper-income classes because the poor has already nothing in the home country. Very poor migrants may not be able to send remittances in the initial years after migration because he migrated by borrowing money or he did not study when he was in his country of origin and so on and so on. So he finds difficulty to send 
money for the first time as he struggles to repay the money he borrowed to migrate or he tries to acquire a skill to get money and start studying instead of working or he is doing a low level job which he is receiving that not much money and struggles to satisfy his own basic needs and cannot send money back home as remittances. Also the remittances of the very rich migrants may be smaller than the loss of income due to migration. But for the middle-income groups, they enable recipients to move up to a higher income group. In Sri Lanka, households from the third through the eighth income declines moved up the income ladder due to remittances (Ratha, 2007). Besides the micro effects, remittances were capable of setting off macro impacts.

Remittances are not "direct investments" in local households which are bereft of the already stated problems nor do they suffer directly from booms and slumps like the foreign aid and foreign direct investment do. Accordingly, when conflicts happen in origin countries, remittances make available and a vital lifeline, interestingly not provided by local governments. On the contrary, aid suffers directly from both grand and petty corruption, bureaucratic delays and are sometimes invested in inferior projects. The Organization for Economic Cooperation and Development (OECD) suggests these arguments (Adams and Page, 2003).

Davis (2005) noted that in Jamaica with the steady growth of money transfers, the social and economic impact of remittances has moved beyond the sphere of households but rather contributed the far more investments, job creation and employments, increasingly played an important role in the economic performance with potential multiplier effect on GDP, consumption and investment and this led the country to boom economically. Further, the Diaspora provides several other important sources of revenue and economic activities to their home countries but not only the Diaspora contributes economic activities but also contribute the social development and the humanitarian assistants in some countries such as Somalia in which will be discussed in the later chapters. Remittances expand the tourism industry and related economic sectors such as airlines and other forms of transportation through the diaspora visits home regularly. Remittances also enhance purchasing products from home while living abroad thereby stimulating growth in nostalgic industries in home countries and this may promote and encourage exportations which leads the economy to grow 
farther. Migrant remittances also cause investment in small businesses in their home countries which can help the employment rate to rise in the home country; and provide financial support to facilitate development and philanthropic initiatives at home (Kibikyo and Omar, 2009).

Whether invested or consumed, remittances have an important macroeconomic impacts of generating positive multiplier effects which increases the both Marginal propensity to Consume (MPC) and also the Marginal Propensity to Save (MPS), while stimulating various sectors of the economy. Adelman and Taylor show that for every dollar that Mexico received from migrants working abroad, the GNP rose by $\$ 2.69$ to 3.17 depending on where the remittances were received either urban or rural households and that is because of the positive multiplier effect of remittances (Rathe, 2003). Other studies analyzing links between remittances and poverty in Ghana (2005) which suggest that raising remittance by 10 percent decreases the share of those in poverty by 3.5 percent and has a negligible impact on income inequality, as measured by the GINI coefficient (Adams, 2005).

Ratha (2003) made a study of about 74 low and middle-income countries and the study suggests that the impact of remittance flows on the poverty headcount might be smaller on average. The point estimate for the poverty headcount measure using survey mean income and it shows that a 10 percent rise in share of remittances in GDP will cause a 1.6 percent decline in the poverty headcount ratio (people living on less than $\$ 1 /$ day). The point estimate for the poverty gap and severity of poverty (poverty gap squared) shows that on average, a 10 percent rise in share of remittances in GDP will cause a two percent decline in depth and severity of poverty, not the poverty gap. What is being talked about is that of the poverty gap squared. The effects of remittances on poverty were under estimated in somehow in the last study. This happened because when it comes to measure remittances; always the large unknown amount remitted through private, unofficial channels is excluded (Adams and Page, 2003).

Ratha (2007) argues that remittances directly augment the income of the recipient households as remittances are additional flow of income to the recipient household and indirectly affect poverty and welfare through indirect multiplier effects and also macroeconomic effects as it will be seen in the later chapters. Cross-country regression 
analysis also shows that significant poverty reduction effects of remittances: a $10 \%$ increase in per capita official remittances may lead to a $3.5 \%$ decrease in the share of poor people. Although with mixed effects across countries, remittances reduced poverty in Sub-Saharan Africa (SSA) and Latin America. Household survey data show that remittances decreased the poverty headcount ratio significantly in several low economies by 11 percentage points in Uganda, 6 percentage points in Bangladesh, and 5 in Ghana. In Nepal, since 1997, remittances may explain a quarter-to-half of the 11 percentage point of reduction in the poverty headcount rate. The extent of poverty reduction as its obvious depends on social class of the migrant (Kibikyo and Omar, 2009).

Home governments have introduced a variety of schemes for migrants with several policy objectives in mind regarding remittances; namely, repatriatable foreign exchange accounts to encourage the greater use of official channels instead of informal ones, foreign currency denominated bonds submitted to the Diaspora in order to encourage more use of financial assets in the home country, and self-employment investment schemes to stimulate more direct investment in productive and profitable ideas and assets. In other instances, governments have resorted to mandatory remittance ratios, requiring migrants to remit a given percentage of their foreign earnings, remittances, through the official channels instead of the unofficial ones, and hence to be converted to domestic currency at the official exchange rate in the home country. In order to encourage migrants to hold their savings balances in financial assets in their "home" as opposed to host countries many governments have introduced foreign currency denominated bonds (Maimbo, 2003). Another policy area concerns schemes to encourage migrants themselves to become investors and invest in their home country. Subsequently they will contribute the economy of the home country to grow by creating more jobs for the people of the origin country. There is substantial scope for policy interventions in the part of Asia Pacific islands as governments wishing to increase the flows of remittances to their economies. All the evidences suggest that migrants' remittances would be responsive to financial needs of the home country. Remittances can be a substitute for the Foreign Direct Investment (FDI), Official Development Assistant (FDA) and also borrowing money from the World Bank and the International Monetary Fund (IMF) sort that have been adopted elsewhere in the Asia-Pacific region to promote migrants' remittances (Buencamino and Gorbunov, 2002). It is generally accepted, however, to encourage the use of remittances, the 
policies implemented to promote longer-term growth and income security in home economies have been a failure. The belief is that policies can be effective in encouraging migrants to: 1) channel and send remittances through official ways and channels, rather than informal channels increase their levels of remittances by encouraging them to hold their savings in financial assets in the home rather than host countries; 2) become, themselves, investors in productive and profitable ideas and assets in the domestic economies of the home countries (FATF, 2003). International remittances represent the second largest and most important source of external funding for developing countries after foreign direct investment. The World Bank (2014) estimates that international remittances to developing countries reached up to $\$ 436$ billion in 2014. Remittances to the East Asia and the Pacific region and the South Asia region account for the largest and second-largest shares in the world as they have the largest world migrants who live upper income countries such as US, Gulf countries and also Western Europe. For South Asia, the economic effects of the remittances are quite robust, effective and successful. International remittances are the largest source of external resource flows of income in the region and have been stably increasing compared to other factors, such as Foreign Direct Investment (FDI) and Official Development Assistance (ODA) as it is shown in (Figure 3) (World Bank, 2014)

Figure 3: Remittances, Foreign Direct Investment (FDI) and Official Development Assistance (ODA) as Share of the GDP-2013

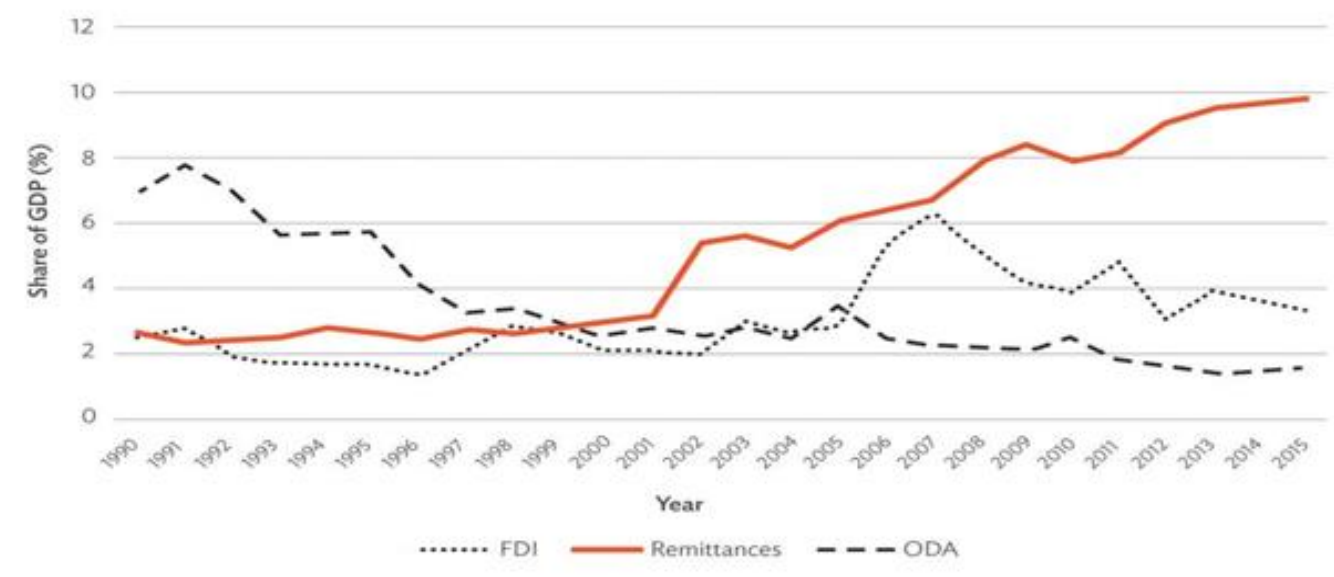

Source: World Bank 
Since the beginning of the 21 st century, remittance flows have accounted for a large proportion of external resources in South Asia. Data for South Asia shows that in 2013, international remittance flows in Nepal were equivalent up to $25 \%$ of gross domestic product (GDP) and 98\% of international reserves, while for Pakistan, international remittance flows were equivalent to $284 \%$ of international reserves (World Bank, 2014).

In a conclusion, Research works on the effect of migration and remittance in different economic variables is increasing year after year. Most of the findings of the studies made indicate that remittance is a positive and significant contributor to boosting the economy and improving welfare indicators. Some studies also indicate that poor people are getting relatively less remittance than richer people due to expensive migration costs, which can increase inequality. Because only those families who can afford sending a person to abroad can receive remittances. The majority of the research found that remittance is used for normal consumption such as the basic needs; however, some found that remittance is contributing to investment or entrepreneurship.

\section{An Over View of Somali Migration and Remittances}

In the pre-colonial period, Somalis were ethnically homogenous, mostly nomadic pastoralists. They were politically organized through a lineage and customary institutions and political systems rather state institutions. The whole land were Somalis live and occupy were colonized by Britain and Italy. The British used to colonize in the North of Somalia while Italians in the South. The Southern part Somalia got its independence from Italy as well as the Northern part got the independence from England in 1960. Then the people of the two parts of the country, Southern and Northern parts, joined together forming a one united Somali government. The people elected their new president Adam Abdulle and agreed Mogadishu to become the Capital of the nation (Gundel, 2003). Although there was an expansion in the export of the livestock but the budgetary report of the country was heavily reliant on foreign support (Gundel 2003; Karp 1960; Lewis, 1994).

In 1969 Muhammad Siad Barre assumes power in coup after Shermarke, the second president of Somalia, is assassinated. In 1970 Barre declares Somalia is a socialist state and 
nationalizes most of the economy. So that people suffered more because the strict rules of the regime government. Private enterprises ware nationalized and all business companies were regulated. But the regime succeeded to reduce hunger, build the infrastructure and emphasized the the importance of education though compulsory school enrolment projects. Barr's Government started to spend lots of money on the war with Ethiopia in 1977 over the dispute border between the two nations, Somalia and Ethiopia, of Ogaden Region (Gundel, 2003; Mansur 1995; UNDP, 2001). International support helped Somalia reduce economic tensions and assisted Somalis to generate revenues domestically. Despite there was anticlanist laws and all clan based manifestations were formally banned still the regime himself was a master clanist who used the government resources for the interest of specific groups (Lewis, 1994).

Detentions and persecutions against any dissenting individuals, groups and political movements started to increase in the country. In 1991 Barre was ousted and over thrown from the power by warlords. Power struggle started between clans. Therefore, so many people were killed, wounded and displaced. In 1991-1992, 240,000 to 280,000 people died from starvation and diseases across the country; only in that short period of time, in southern and central Somalia alone, more than 40,000 people were killed in fighting as the region entered a long period of inter-clan warfare, banditry and famine (UNDP, 2001). Civil war severely damaged the life of the civilians. Education, healthy and all the other basic needs disappeared. The UN tried to deliver aid to the needy people. Unfortunately, Somali clan based warlords denied the aid to be delivered to the needy people. After that, the United Nations tried hard to stabilize Somalia thorough multiple Somali reconciliation processes but any of those attempts did not work. Therefore, people started to lose hope and seek better place for better life feeling from their home country to rest of the world which they thought they could get some life better than the one in Somalia.

\subsection{Migration in Somalia}

Somalis lived in the horn of Africa and largely they were nomadic pastoralists or agropastoralists. They used to move and migrate regularly even beyond their 1960s borders with Djibouti, Ethiopia and Kenya looking for water and grace for their livestock. Also Somalis 
used to migrate not only looking for water and posture for their livestock but also for trade and work within or beyond the border. Some longer migration baths were created by the colonial occupations of Italy (to the South) and Great Britain (to the North). For example, in the north region of Somalia, young men from the pastoralist families were recruited to the British Merchant Navy to work in the engine rooms of cargo steamers (Hussein, 1993).

From the year of 1973, many Somalis migrated to the booming economies as construction laborers, drivers, house cleaners and maids, guards and some worked in occupations which require skills. Examples of those occupations which require skills include carpentry, cooking, electricity, and heavy truck and machinery driving (Sheikh Ali, 1997). Particularly after the prolonged drought, which most Somalis named it as (Dabadheer) in the mid of 1970s, the Somali people were keen to seek better life and better economic opportunities (Gaani, 2005). In the mid of 1980 most business men in the Somali cities had relatives in the Gulf countries, mainly in Saudi Arabia (Simons, 1995). Most of those Somalis in Saudi were young men and single whose hope was to come back to their home country after a short period of time because the Saudi regime didn't allow for any foreigner a permanent stay in Saudi (Mohammed, 2000). In 1970s, urban wages were more or less stagnated, but between 1970 and 1978 inflation doubled. However, in the 1980, Somalis working in the Gulf countries were earning at least five to six times the average Somali wage. Also, they remit perhaps around one third of those wages to Somalia (Jamal, 1988). By the end of 1980s remittances and the overseas Somali population was already playing a significant role in the economy of the country. As Jamal (1988) argues that remittances and trading activities, rather than waged employment, met the basic needs of most urban families. The outbreak of the civil war in 1988 and the collapse of the central government in 1991 dramatically affected the patterns of emigration. As the regime rule of dictator Barre was sinking into economic and political crises, the foreign aid started dwindling and a shrinking formal economy to milk. People started to flee from the country because of collapse of the government. Up until now, people of Somalia are migrating from the country because of insecurity, poverty, poor health and diseases, droughts and famine, unemployment and many more. Somali international migrants are estimated one to two million right now (World Bank, 2016). Somali international Migration is increasing time after time. Neighboring countries 
such as Ethiopia and Kenya, Europe and the United States of America are the destinations of most Somali international migrants.

Figure 4: Somali Diaspora Population Living Abroad-2009

Source: Pew Research Center

The above chart shows some of the countries in Africa, Europe and the North America which host the most and the largest number of Somali international diaspora around the world.

Today the Somali Diaspora population around the world is estimated more than to one million Somalis. That number makes $14 \%$ of the whole Somali population live abroad (UNDP, 2009). UK has the largest Somali Diaspora in Europe. The Netherlands, Norway, Sweden and Italy come next. North America, Canada and United States of America, have large Somali Diaspora population, even larger than the Somali Diaspora population found in UK and Sweden. Minneapolis, Toronto and Ohio have big Somali Communities.

\subsection{Remittance Flows in Somalia}

It is believed that the west is the most significant source of remittances since the labor market tightened in the Gulf and the refugee crisis occurred in the 1990s. Somalian refugees in neighboring countries to send much smaller amounts than those Somali Diaspora in elsewhere around the world or we can say they are more likely to receive (from elsewhere in the diaspora) than send remittances, (Horst, 2003). 
Somali Diaspora living and working abroad has a significant and vital role in the Somali economy regardless of their differences in gender, demographic and qualifications. They also contribute to the livelihoods of the Somali people back home. They also contribute to the recovery of the economy which has been destroyed and collapsed. In 2004, the remittances sent by the Somali Diaspora around the world was estimated about one billion dollars each year (UNDP, 2004). That makes the country the fourth most remittance dependent country in the world. That amount includes remittances sent to families and other relatives, for humanitarian assistances and for investing small and medium enterprises. Like the Somali Diaspora population, it is not easy to estate the exact volume of remittances sent by Somali international migrant workers to Somalia. Sometimes, it is commercially sensitive to get information from the Somali remittance companies and it is not easy to disaggregate transfers of funds to the country from the transfers of funds within the Diaspora. Even, it is not easy to distinguish between funds transferred for livelihood purposes, funds transferred for investments in land properties and the one for other business purposes. Recent research report show that the flow of remittances to Somalia reaches more than one billion US dollars each year and to Somaliland up to more than 700 million US dollars (Lindley, 2007). Another way of trying to estimate remittances to Somalia is to make surveys in household incomes, but still, here is another problem of people tending to under report their incomes. A household survey made in 2002 indicated that incomes of only US\$360 million (Lindley, 2007). Somali Diaspora in American which has been estimated over 150,000 people are the highest contributors; they send an average of $\$ 3,800$ per person annually, according to a 2013 study published by Oxfam. The money is a lifeline for thousands of families, who rely on remittances to get basic needs such as food and shelter, pay for education and health services, and sustain their small scaled businesses. Sending remittances is also a testament to something else which is the fantastic expression of faith, generosity, and solidarity which is common among Somalis. 
Figure 5: Annual Amount Sent in Millions-2013

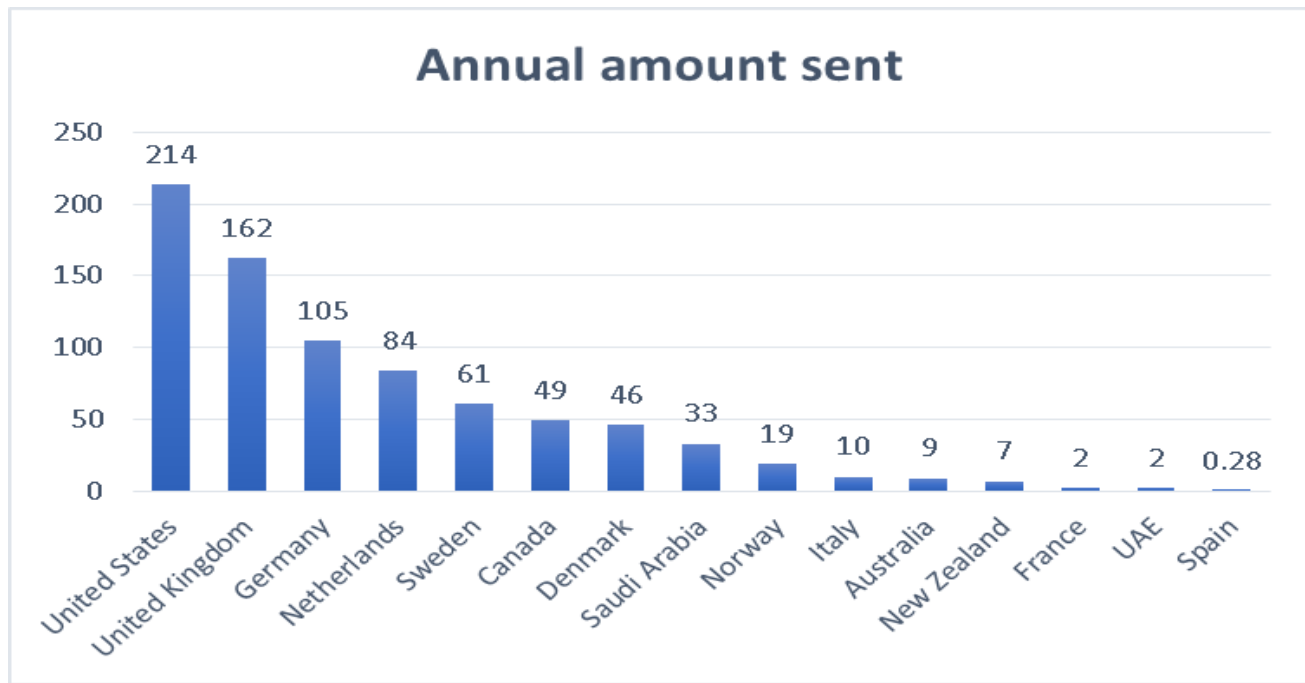

Source: Pew Research Center

$23 \%$ of the Somali household incomes come from the Somali Diaspora living and working abroad (UNDP/World Bank, 2003) but are unequally distributed across the country. People live in rural areas do not get that much remittances as the people live in cities who have much more relatives live in abroad. Up to $25 \%$ of the households in Hargeisa claim that remittance is their sole source of income as a survey made in Hargeisa shows. These are used for expenses on basic needs like food, housing, health services and education (Lindley, 2007). Remittances flow to Somalia totaled US\$ 1.4 to 2 billion in 2016. With a Remittances to GDP ratio of $23 \%$. Somalia is a highly remittance dependent country as shown in Figure 1. Official Development Assistance (ODA) for Somalia is another key flow for Somalia, estimated at US\$ 1.3 billion in 2016 (21\% of GDP). According to the 2017 Somalia Economic Update (SEU), remittances and aid are fueling Somalia's consumption-driven growth. 


\section{Figure 6: Financial Flows as \% of GDP-2016}

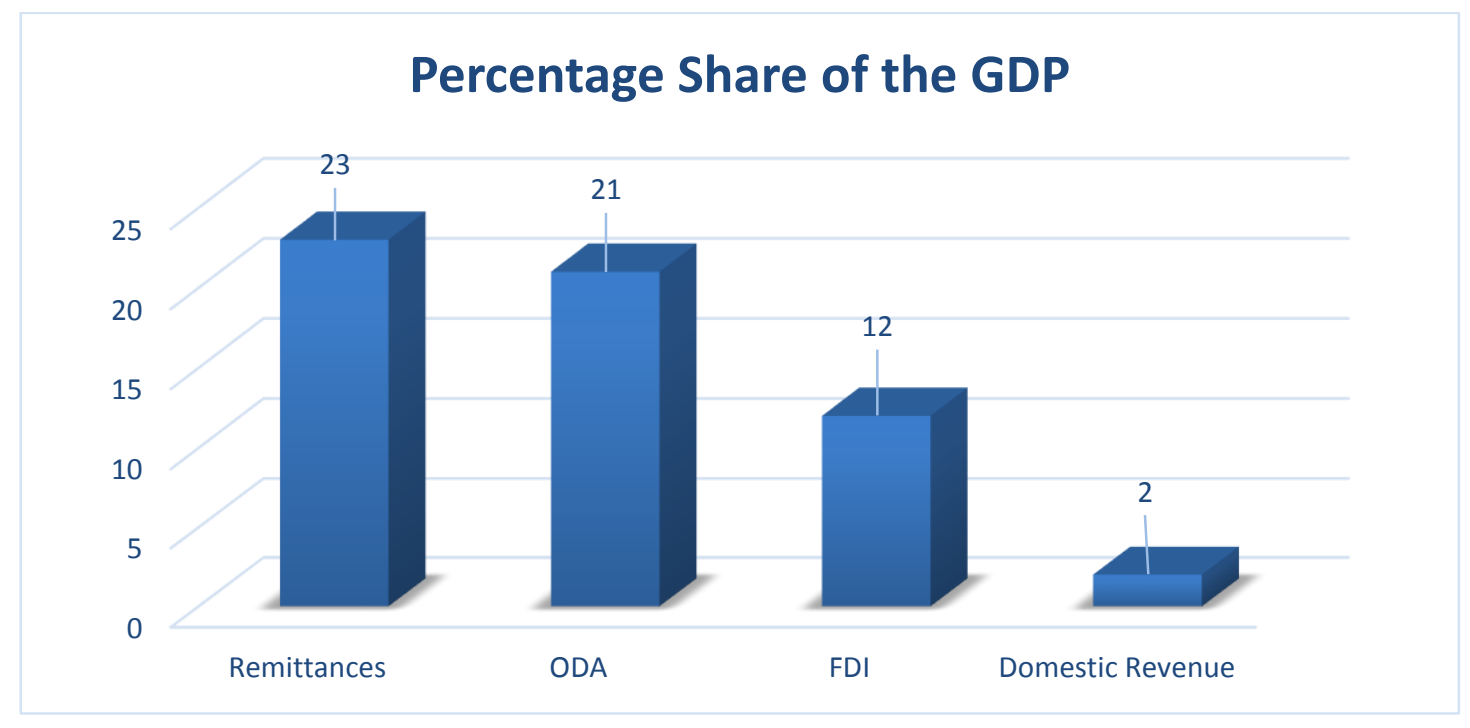

Source: World Bank

Men are not the only ones who send money back home but there are some evidences showing that women contribute too as the case of Somali women Diaspora in Norway who are increasingly important contributors. It is not just a benefit for those who left behind back home but also remittances are good and have that significant social. Although remittances are a lifeline, at the same time they are the glue that bonds together between the families who separated physically by distance. Remittances result strengthening this transnational community that exists in multiple localities. Therefore, in case of inability or failure to remit weakens the ties between families and societies as Laura Hammond argues. That also can sow the seeds of conflict and estrangement of the sender (Hammond, 2007).

\section{Remittances and Poverty Reduction in Somalia}

51 percent of the Somali population live in a situation of poverty, as defined by having a total daily per capita consumption expenditure lower than the international poverty line of US\$1.90 at 2011 PPP, which equals to 34,341 Somali Shillings per day per person in 2016. In addition to that, 31 percent of Somalis have a total daily per capita consumption expenditure of less than US\$1.25, expressed at $2011 \mathrm{PPP}$, leaving them in a condition of extreme poverty (World Bank, 2016). If we look at the survey of Somali High Frequency Survey (SHFS) by the World Bank, households who do receive remittances, we can notice that poverty incidence 
of household recipients is $18 \%$ lower than the poverty incidence of non-recipient households as it's illustrated in the following diagram.

Figure 7: Poverty Incidence Among Recipient And Non-Recipient Households-2016

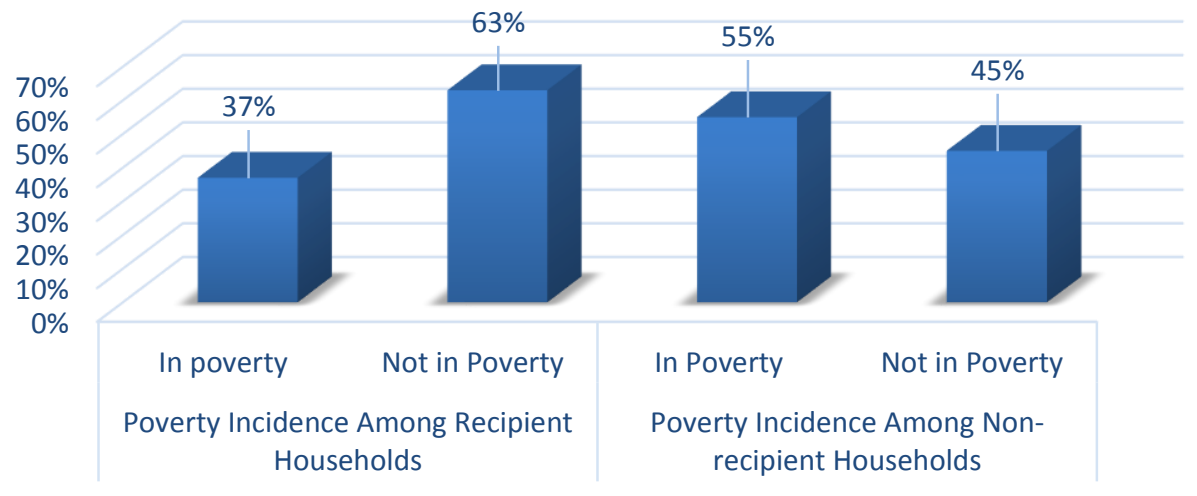

Source: World Bank

Many recipient households rely on an only one single sender and could not know how to afford basic consumption and services without this source of income, remittances. Therefore, while remittances increase the welfare and the standards of living of households fortunate enough to receive remittances, the lack of other means for generating income puts them in danger position of falling into poverty in case of losing their remittances as a source of income.

\subsection{Research Design}

To explain the impacts of remittances on poverty in Somalia, we offered different simple regression models since influencing factor of remittances is a single independent variable to test our hypotheses derived from the literature. These hypotheses include several causative relationships between our independent variable and various dependent variables. In this study, a secondary data is collected from World Bank Database. In order to explain the impacts of remittances on the poverty of Somalia, we evaluated the impacts of remittances on poverty head count ratio, poverty gap, poverty severity, inequality and family small businesses. The data of about remittances, poverty head count rate, poverty gap, poverty severity, inequality and family small businesses is taken from the World Bank survey called Somali High Frequency Survey (SHFS) in 2016 which covered most of the regions in 
Somalia. The regions are as classified as flows: North East Urban (NEU), North East Rural (NER), North West Urban (NWU), North West Rural (NWR), Mogadishu and its Surroundings and the IDP (Internally Displaced Person) Settlements all across the country. But when talking about Remittances and the GDP nominal, the data taken from the IMF and ranges from 2004 to 2017. Simple regression is a statistical technique used to assess the magnitude and direction of the relationship between a criterion variable and a predictor variable. Ordinary Least Squares (OLS) regression analysis will be used to estimate the models. OLS regression was selected for two reasons. First, it is a widely accepted statistical procedure for exploring and predicting the relationships among different variables. Second, the results of regression are easy to interpret. Regression runs with variables against each criterion variable and the results are reported in the findings in a subsequent title. The OLS regression models used variables as given in the following;

$Y 1 . . n=a+b X+e$

Where; $\mathrm{X}=$ Remittances,

Y1..n = GDP growth, Poverty Head Count Rate, Poverty Gap, Poverty Severity, Inequality, Small Family Businesses and the Gross School Enrolment. e = Error term.

\subsection{Remittances and the Poverty Headcount Ratio}

Poverty is defined as having a total consumption expenditure which is lower than the international defined poverty line of US\$1.90 at 2011 PPP (World Bank, 2011). Poverty headcount ratio measures the proportion of the population that is poor. It is popular because it is easy to understand and measure. But it does not indicate how poor the poor are (World Bank Group, 2018). Poverty varies considerably across the Somali population, ranging from 26 to 70 percent. Regional differences in poverty ranging between the North East (27 percent) and the North West (50 percent) are much larger than urban/rural difference (45/52 percent). In urban areas, poverty varieties from 26 (North East) to 57 percent (Mogadishu). In rural areas, poverty ranges from 34 percent (North East) to 61 percent (North West). Poverty incidence is at its highest in IDP settlements where seven out of ten people are poor (70 percent), while more than 1.1 million Somalis, roughly 9 percent of the population, considered internally displaced. At 51 percent, the poverty rate is in line with the regional 
average of low-income countries across Sub-Saharan Africa (World Bank, 2016). As the study of the SHFS by the World Bank shows, every fifth Somali household receives remittances but the likelihood of receipt differs from 7 to 32 percent across regions, leaving vulnerable populations, especially IDP settlements, relatively excluded. Mogadishu and the rural North East regions have the highest incidence of households receiving remittances (both 32 percent), followed by urban households in the North West (24 percent) and North East regions (23 percent), and rural North West region (13 percent). Households in IDP settlements are least likely to receive remittances at 7 percent, more than 50 below average.

\section{Figure 8: Poverty and Remittance Incidences in the Selected Areas-2016}

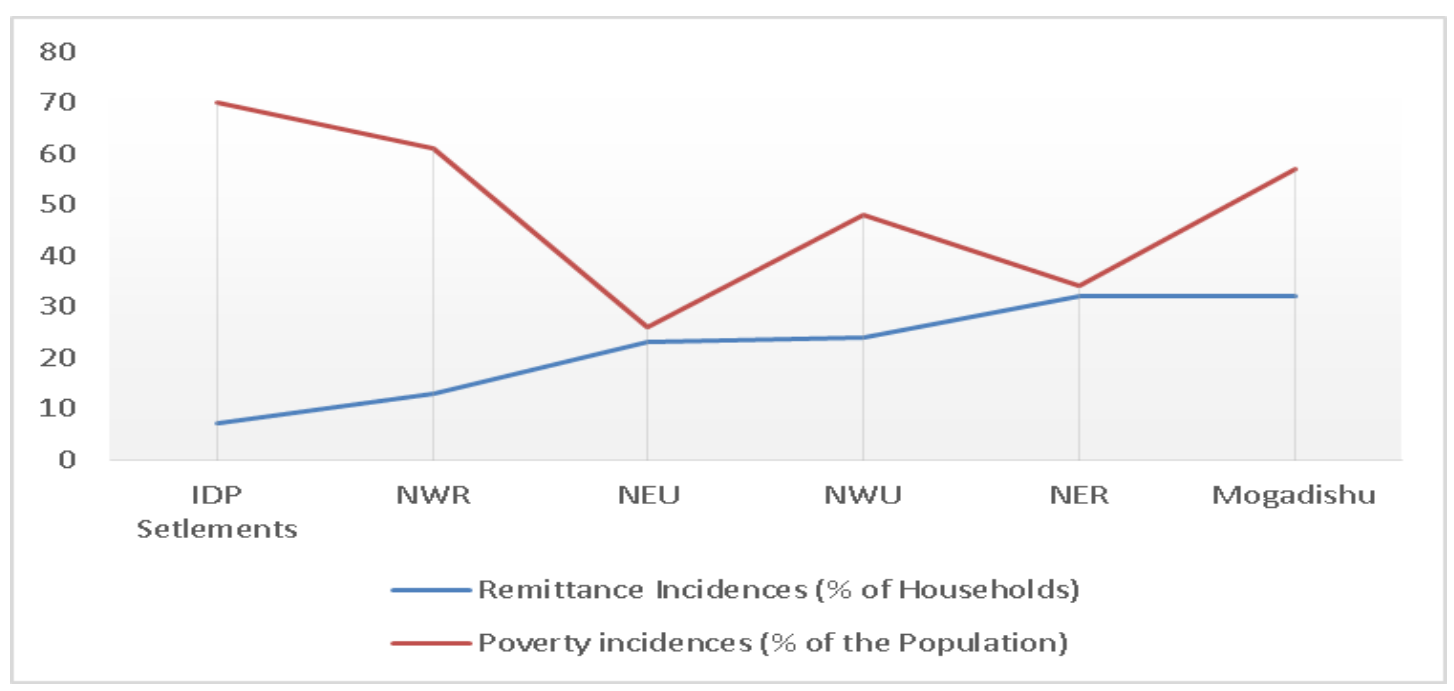

Source: World Bank

R Square $=0.374708885$, Adjusted R Square $=0.218386106, P$-value $=0.196484112$, $\mathrm{b}=-1.015530179$. After the data has been analyzed using the method of Ordinary Least Squares, we found that there is a negative relationship between remittances and poverty incidences among the households in the different regions and areas in Somalia as (b) which is the coefficient of the equation found is less than zero $(b=-1.015530179)$. But the variance is not significant as $P$-value is greater than 0.05 . So the idea stated in the literature review which is remittances have no significant impact on poverty is supported by the case in Somalia. 


\subsection{Remittances and the Poverty Gap in Somalia}

Poverty gap calculates the total amount of money by which each individual falls below the poverty line. It matters here whether income and the poverty line are measured on a per capita basis or whether they have been put into adult equivalent terms or adjusted for scale economies (Milanovic, 2002). It measures the extent to which individuals fall below the poverty line (the poverty gaps) as a proportion of the poverty line. The sum of these poverty gaps gives the minimum cost of eliminating poverty, if transfers were perfectly targeted. The measure does not reflect changes in inequality among the poor (World Bank Group, 2018). In a similar way, the Somali poverty gap index at 22 percent is in keeping with the Sub-Saharan low-income average of 20 percent, where once again there are huge differences underlying the regional averages as shown in the figure below.

\section{Figure 9: Remittance and Poverty Gap Incidences Among the Regions-2016}

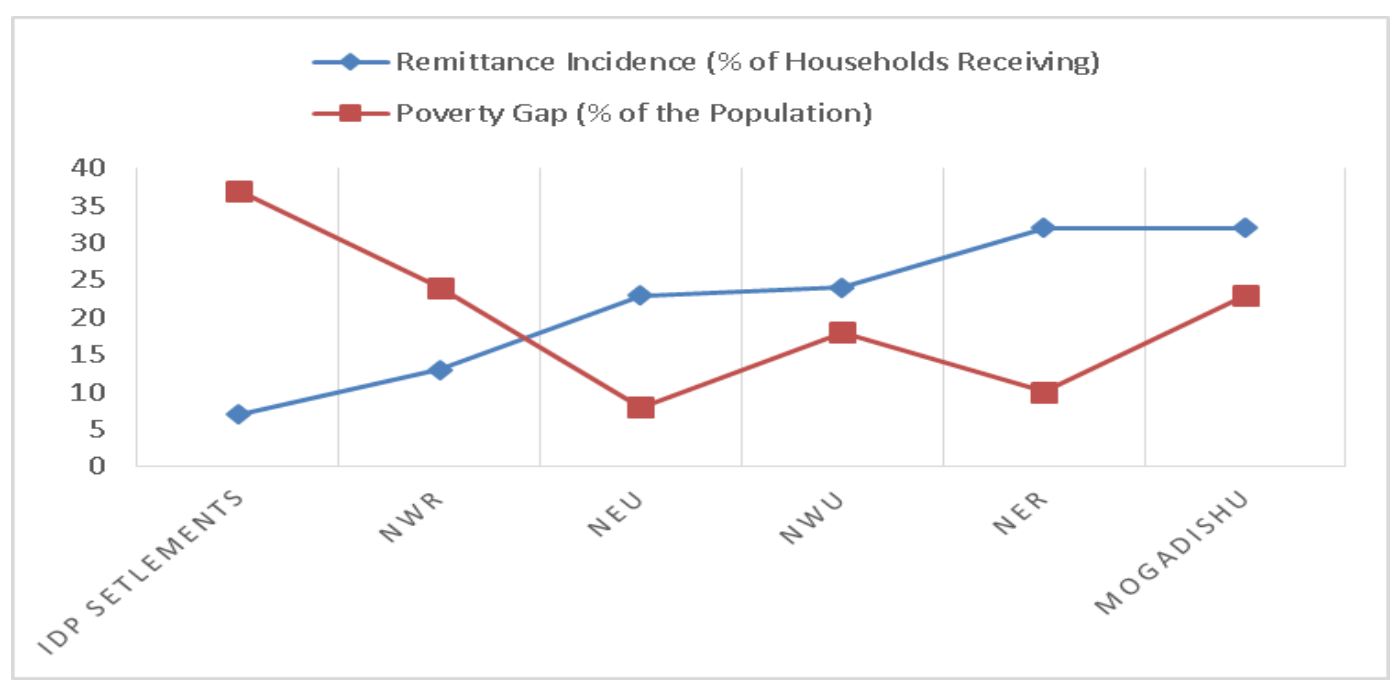

Source: The World Bank Group

R Square $=0.457492493$, Adjusted R Square $=0.321865617$, P-value $=0.11875$, $b=-0.70933115$. The coefficient of the found equation is less than zero meaning that there is $a$ negative correlation between remittances and poverty gap in Somalia and still we can predict the poverty levels of the other regions as we get the level of remittances they receive. But once again the relations is not significant as P-value is greater than 0.05 meaning that the idea and the conclusions of several studies stated in the literature review which are telling that remittances have a tangible impact on poverty gap is not supported in this case of Somalia. 


\subsection{Remittances and Poverty Severity in Somalia}

Squaring the poverty gap (severity of poverty) provides an indication of inequality among the population living below the poverty line, in other words severity of poverty is a measure of the severity of deprivation of those people living in absolute poverty. The squared poverty gap ("poverty severity") averages the squares of the poverty gaps relative to the poverty line (World Bank Group, 2018). In the case of Somalia poverty severity varies between regions like just poverty headcount ratio and the poverty gap as shown in the following figure.

Figure 10: Remittances and Poverty Severity in Somalia-2016

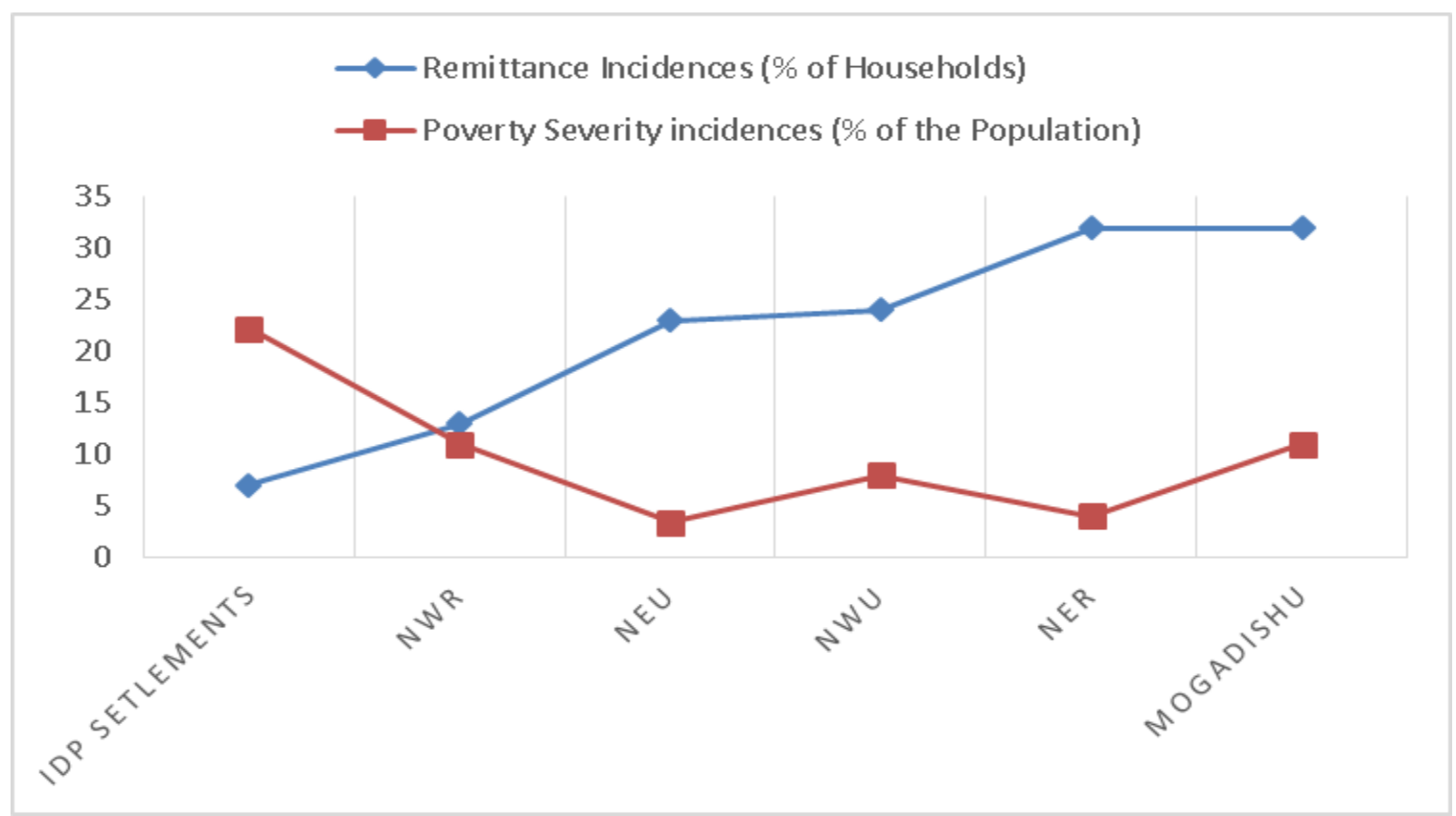

Sources: World Bank

R Square $=0.544585989$, Adjusted R Square $=0.41652814, P-$ value $=0.09, b=-0.49$.

In this case remittances have a tangible impact on poverty severity. Although the significance is still weak, but according to the impacts of remittances on poverty headcount ratio and the on the poverty gap, remittances have a slight significance on the poverty severity. All the results of the multiple researches made mentioned in the literature review which were suggesting that remittances have a tangible impact on poverty severity is supported by the data about Somalia. 


\subsection{Remittances and Inequality Among Somalis}

Inequality — the state of not being equal, particularly in status, rights, and opportunities -is a concept very much at the heart of social justice theories. However, it is prone to confusion in public debate as it tends to mean different things to different people. Some distinctions are common though. Various authors distinguish "economic inequality", mostly meaning "income inequality", "monetary inequality" or, more broadly, inequality in "living conditions". In Somalia poverty and inequality are positively interrelated. A clear trend emerges when comparing inequality across regions and livelihoods: poorer areas are also more unequal. Poverty is least widespread in the North East, where inequality is also lowest with a Gini index of 32 percent. As it is clear in the Somali High Frequency Survey (SHF) which was conducted at the end of the year of 2016 in Somalia, households in Q5 (the top 20 percent in terms of consumption expenditure) consume around 5 times more than households in Q1 (the bottom 20 percent). In stark contrast, IDP settlements are poorest and at the same time most unequal, where the Gini index is 38 percent and Q5 households have more than 7 times higher consumption than Q1 households. This relationship between poverty and inequality notably hinges on the consumption levels of the poorest: in regions where poverty is widespread, inequality is high because the poorest consume so little that they are much worse off than wealthier households. However, while some certain Somali regions are demonstrably more unequal than others, these variations are within a rather small range, especially when compared to the variation in inequality in the sample of low-income SubSaharan African countries. As such, even the high inequality found in IDP settlements is still below the average of this comparison group. Inequality in urban areas is higher than in rural areas, driven by wealthy urban individuals. While rural areas are overall poorer than urban areas (poverty headcount rural: 52 percent, urban: 45 percent), their consumption levels are more homogeneous and hence inequality is lower (Gini rural: 33 percent, urban: 36 percent). 


\section{Figure 11: Remittances and Inequality Among Somalis-2016}

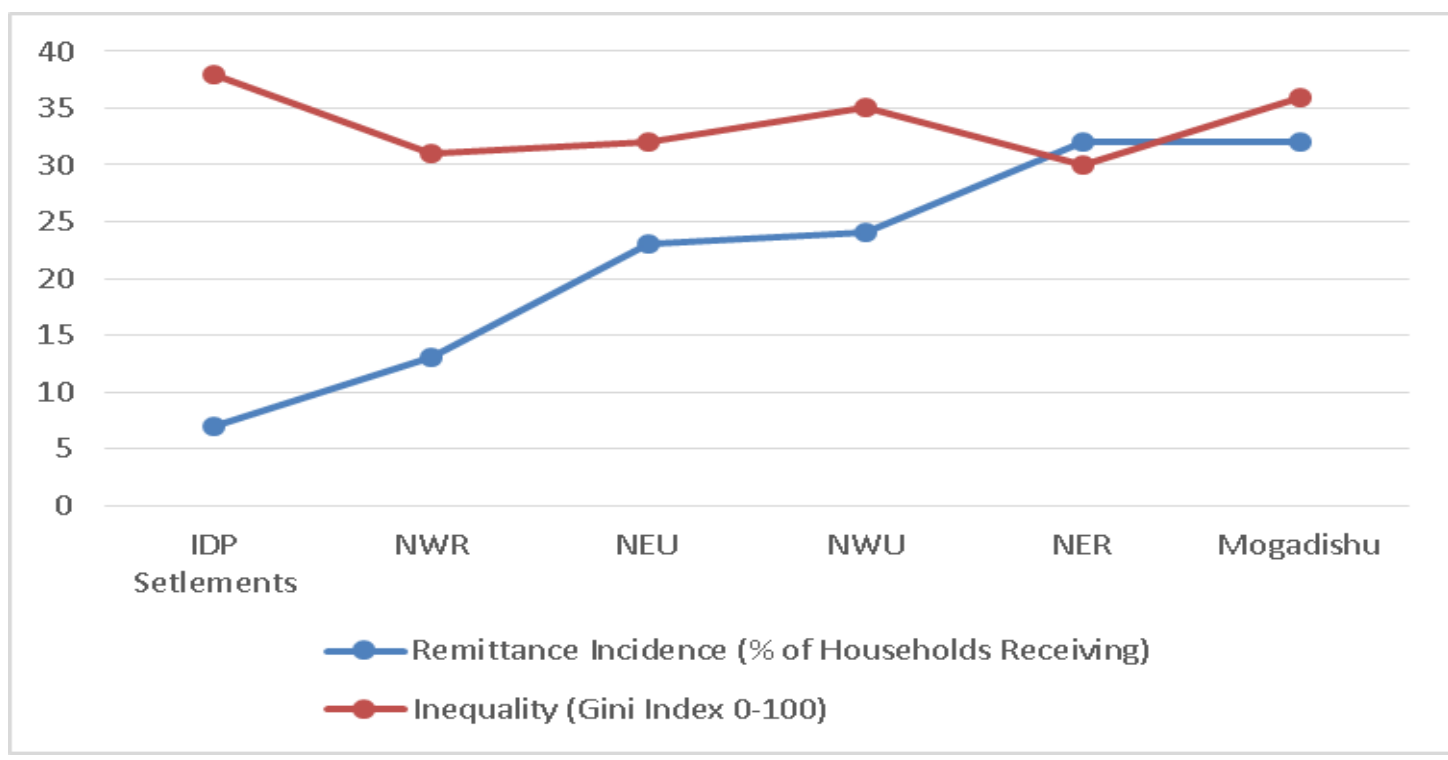

Source: World Bank

R Square $=0.112869803, P$-value $=0.515018406, b=-0.104404568$. Remittances in Somalia have no any significant impact on economic inequality in Somalia. Although we can argue that remittances have the negative relation with the inequality among people in Somalia as the found equation shows in which the coefficient is less than zero but still an increase in the amount of remittances received by the people in Somalia have a necessary impact on the inequalities among the people in Somalia.

\subsection{Remittances and Small Family Businesses in Somalia}

Remittances directly add to the incomes of the family and that helps the family their propensity to save to be increased. After that they will be able to save for investment (Rather, 2015). Many households in Somalia save a portion of their incomes they receive as remittances from the relatives living abroad to start their own family small business and that might reduce the poverty in Somalia. The Wave of the Somali High Frequency Survey, conducted by the World and the Somali authorities, shows that there are differences among the regions in terms of the percentage of households having their own small business. As illustrated in the upcoming figure North East Rural have has the highest percentage of households having their small family businesses. Whereas North East Urban, North West Rural and Mogadishu have the same percentage of households with their own small family 
business. North West Urban and the IDP settlements have the least percentages of about 7 and 7 percent respectively (World Bank, 2016).

Figure 12: Remittances and Small Family Businesses in Somalia-2016

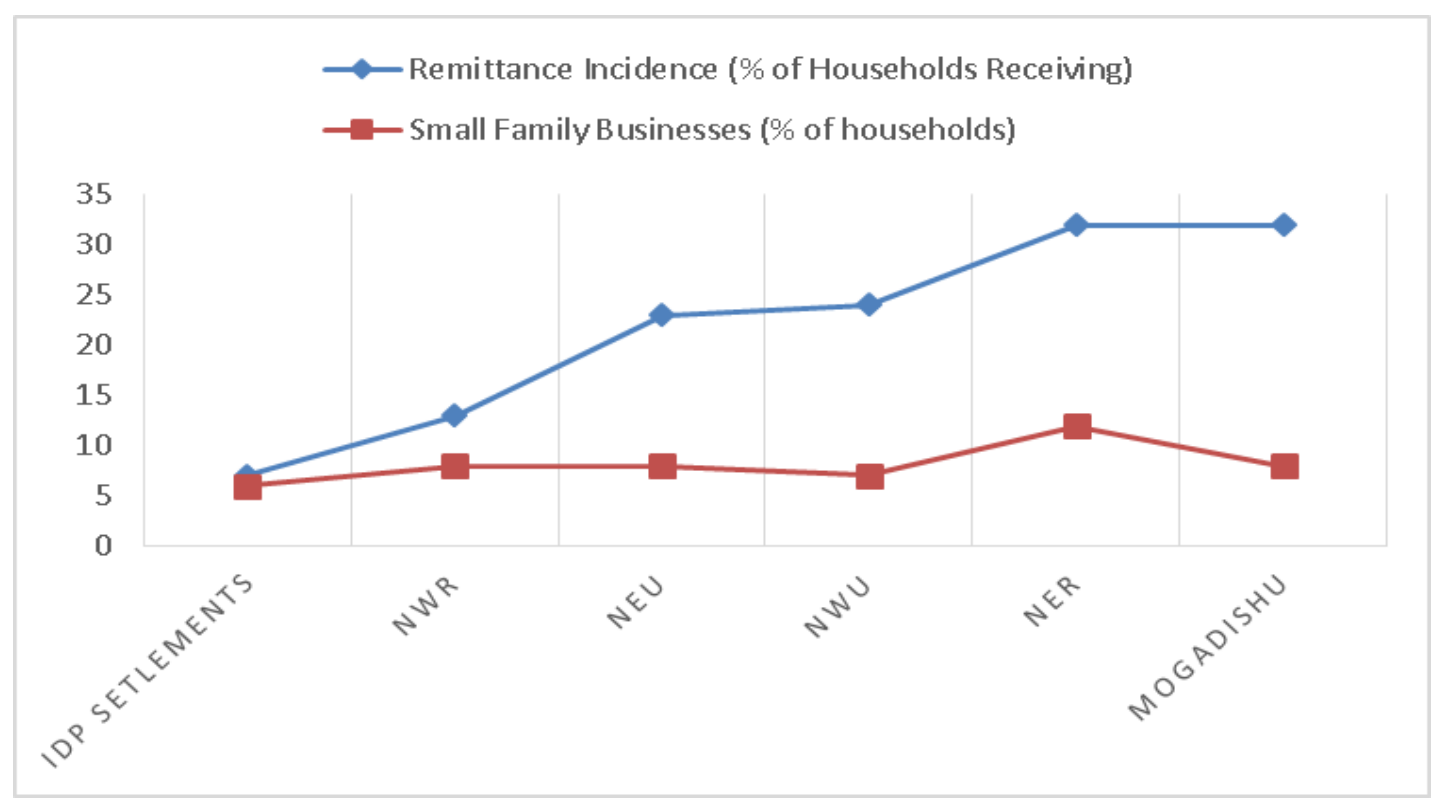

Source: World Bank

$\mathrm{R}$ Square $=0.436623$, Adjusted R Square $=0.295778, \quad P$-value $=0.153093, \mathrm{~b}=$ 0.133442. Remittances have the positive correlations with the small family business but this correlation is not significantly supported in the case of Somalia as the data in Somalia shows.

\section{Conclusion}

International migration and remittances are important part of globalization in the twenty-first century. The scale and the level migration and remittance flow towards developing countries are attracting the attention of many researchers but there is limited research on this area. Global migrations help development but there are policy matters about cross-border migration. As a result, migrant worker remittance and development linkage analysis is now an important issue.

In Somalia after the central government collapsed, civil war severely damaged the life of the civilians. Education, healthy and all the other basic needs disappeared. Lots of people lost their precious lives for no reason. Poverty, hunger and famine become normal among the 
people of Somalia. Deadly diseases started to spread across the country. People started to flee from their home country to the rest of the world to get a living which is better than the one in their home country and to help at least their relatives back home get the basic needs remitting to them.

Remittances to Somalia is the blood of the economy of the country representing more than 23 percent of the overall GDP of the nation. Remittances are forming the largest external source of financing for the Somalis greater than even both the Foreign Aid, Official Development Assistants (ODA) and the Foreign Direct Investments (FDI). Also remittances can be a fixer for the problems of trade balances of the country if remittances are well managed. Remittances can also promote economic growth and development in Somalia. As families get enough amounts of remittances they will be able to save some of the remittances for investments, starting new businesses or expending existed ones, making capital accumulations, generating farther profits and creating new jobs for the people of Somalia.

This research is aimed to analyze remittances in Somalia and their impacts on the poverty in Somalia. Up to51 percent of the population in Somalia live in poverty. The poverty is widely spread across the regions in Somalia. North Eastern region has the smallest poverty incidence according to other regions. People in IDP settlements have he the highest poverty incidence across Somalia.

In order to analyze the matter, we used the secondary data from the World Bank. Ordinary Least Square (OLS) has been used for the analyses. The results found are that remittances has a negative impact on poverty headcount, poverty gap, poverty severity and also inequality in the regions of Somalia.

The relations between remittances and poverty headcount ratio in Somalia is not significantly supported by the case of Somalia. Therefore, remittances in Somalia has no a tangible impact on poverty headcount ratio in Somalia. But when it comes to the poverty gap and the poetry severity in the regions of Somalia, it seems that remittance has an active role in reducing both of them more than it does in the poverty headcount ratio in Somalia. Also there is no a significant relation between remittances and the inequality among Somalis. 
When it comes to the small family businesses remittances, remittances represent as an additional outsource income to the families of Somalia which helps them meet their basic needs and requirements in life and also their propensity to save to be increased. But in the case of Somalia remittances are consumed more than it is saved. The result we found in this research article is that remittances in Somalia have the positive correlations with the savings in Somalia but that correlation is not significant as it was required. Therefore, the idea saying that remittances contribute to the increase of small family businesses is not supported by the case of Somalia.

In order remittances flow to Somalia to be affective and useful the Somalia authorities need to establish formal ways and channels of remittances in order to mitigate any wrong doings and leakages to the terrorist groups through the formation of informal ways and channels of sending remittances. To do so remittances should be exempted from taxes. Because the more taxes is put on remittances the more informal ways of remitting money are formed.

\section{References}

Acosta, P., Fajnzylber, P., \& Lopez, H. (2007), “The Impact of Remittances on Poverty and Human Capital: Evidence from Latin American Household Surveys" (World Bank Policy Research Working Paper No. 4247). Washington, D.C.: The World Bank.

Adams, J. (1991), “The Effects of International Remittances on Poverty, Inequality and Development in Rural Egypt” (Research Report 86). Washington, D.C.: International Food Policy Research.

Adams, J. (1998), Remittances, "Investment, and Rural Asset Accumulation in Pakistan", Economic Development and Cultural Change, 47, 155-173.

Adams, J. (2004), "Remittances and Poverty in Guatemala", (World Bank Policy Research Working Paper No. 3418). Washington, D.C.: The World Bank. 
Adams, J., \& Page, J. (2005), "Do International Migration and Remittances Reduce Poverty in Developing Countries?” World Development, 33(10), 1645-1669.

Adams, J. (2006), "Remittances and Poverty in Ghana", (Wolrd Bank Policy Research Working Paper No. 3838), Washington, D.C.: The World Bank.

Adams, J. (2011), "Evaluating the Economic Impact of International Remittances on Developing Countries Using Household Surveys: A Literature Review”, Journal of Development Studies, 47(6), 809-829.

Adams, J., Cuecuecha, A., \& Page, J. (2008), “The Impact of Remittances on Poverty and Inequality in Ghana”, (Wolrd Bank Policy Research Working Paper No. 4732). Washington, D.C.: The World Bank.

ADB (2010), "Key Indicators for Asia and the Pacific 2010", Manila: Asian Development Bank.

Addison, T., Mursheid, S. M. and Le Billon, P. (2000), "Finance in Conflict and Reconstruction”, Finance and Development Research Programme Working Paper No. 120. Manchester: IDPM.

Adhikari, A. (2010, December 30), "2010 Turns into 'The Year of Banda'”, The Kathmandu Post, Retrieved January 10, 2014.

Ahmed, I. I. (2000), "Remittances and Their Economic Impact in Post-war Somaliland", Disasters, 24(4): 380-389.

Al-Sharmani, M. (2004), "Refugee Livelihoods - Livelihoods and Diasporic Identity Constructions of Somali Refugees in Cairo", New Issues in Refugee Research Working Paper No. 104. Geneva: UNHCR Evaluation and Policy Analysis Unit.

Amuedo-Dorantes, C., \& Pozo, S. (2004)., "Workers' Real Exchange Rate: A Paradox of Gifts", World Development, 32, 1407-1417. 
Amuedo-Dorantes, C., \& Pozo, S. (2006), "Remittance Receipt and Business Ownership in the Dominican Republic", The World Economy, 29(7), 939-956.

Anyanwu, J., \& Erhijakpor, A. (2010), “Do International Remittances Affect Poverty in Africa?", African Development Review, 22(1), 51-91.

Awdal News Network (2003), "Remittance Companies Stiffly Cautioned against Status Change", Awdal News. 21 June. Available at http://www.awdalnews.com.

Bang Nielson, K. (2004), "Next Stop Britain: The Influence of Transnational Networks on the Secondary Movement of Danish Somalis”, Working Paper No. 22, Brighton: Sussex Centre for Migration Research.

Besteman, C. and Cassanelli, L. V. (eds) (1996), The Struggle for Land in Southern Somalia, London: HAAN Publishing.

Bradbury, M. (2002a), Somalia: The Aftermath of September 11th and the War on Terrorism, Unpublished report for Oxfam.

Castaldo, A., \& Reilly, B. (2007), “Do Migrant Remittances Affect the Consumption Patterns of Albanian Households?", South-Eastern Europe Journal of Economics, 1, 25-54.

Cattaneo, C. (2009), "International Migration and Poverty: Cross- Country Analysis", Retrieved December 7, 2011, from http://www.dagliano.unimi.it/media/ Cattaneo Cristina.pdf.

Chequepoint Money Transfer (2004), "Memorandum Submitted by Chequepoint Money Transfer to the Migration and Development International Development Select Committee", Available at http://www.publications.parliament.uk.

Devkota, J. (2015), “Impact of Migrants' Remittances on Poverty and Inequality in Nepal”, Forum of International Development Studies, 44, 36-53. 
Duale, A-K. F. (1998), "Reconstructing Life in the Diaspora: British Immigration Law and Policies and Somali Patterns of Adaptation", In Variations on the Theme of Somaliness, Turku: Åbo Akademi University.

Duffield, M. (2001), Global Governance and the New Wars: The Merging of Development and Security, London: Zed Books.

Duhul, S. F. (2002), "Somalia: Remittance Firms Continue Services despite Constraints", Arab News, Available at http://www.realpuntlander.com.

European Commission (EC) (2002), "European Commission Strategy for the Implementation of Special Aid to Somalia 2002-2007", Brussels: EC.

Economist (2003), “Britain's Somalis - Muddled Minority”, The Economist, 27.

EIU (2002), "Country Report: Ethiopia, Eritrea, Somalia and Djibouti”, London: The Economist Intelligence Unit.

EIU (2004), “Somalia Country Profile 2004”, London: The Economic Intelligence Unit.

El Qorchi, M., Wilson, J. F. et al. (2002), "Informal Funds Transfer Systems: An Analysis of the Hawala System", Washington DC: International Monetary Fund and World Bank.

Eldin Eltayeb, S. (2004), "Central Bank Registers All Somali Remittance Agents", Khlaaj Times (Dubai), 25 June.

FATF (Financial Action Task Force) (2001), "Special Recommendations on Terrorist Financing. Paris", FATF Secretariat.

Golden, T. (2002), "A Nation Challenged: Money; 5 Months After Sanctions Against Somali Company, Scant Proof of Qaeda Tie", New York Times (New York), 13 April.

Gundel, J. (2003), “The Migration-Development Nexus: Somalia Case Study”, In Van Hear, N. and Nyberg Sørensen, N. (eds), The Migration-Development Nexus, Geneva: IOM. 
Hansen, P. (2004), “Migrant Remittances as a Development Tool: The Case of Somaliland”, Migration Policy Research Working Paper Series No 3. Copenhagen: University of Copenhagen, Department of Policy Research and Communications.

Home Office (2003), “Control of Immigration Statistics”, 2002. London, HMSO.

Horst, C. (2003), “Transnational Nomads - How Somalis cope with refugee life in the Dadaab camps of Kenya”, PhD diss., University of Amsterdam.

Horst, C. (2004), "Connected Lives: Somalis in Minneapolis dealing with Family Responsibilities and the Migration Dreams of Relatives", Paper presented at the 9th Somali Studies International Conference, 3-5 September, University of Aalborg, Denmark.

Hussein, Shamis. (1993), "Somalis in London", In Merriman, N. (ed.), The Peopling of London, London: Museum of London.

Ratha, D. (2005), “Workers' Remittances: An Important and Stable Source of External Development Finance", In Maimbo, S. \& Ratha D. (Eds.), Remittances: Development Impact and Future Prospects, (pp. 19-52), Washington, D.C.: The World Bank.

Sapkota, C. (2013), “Remittance in Nepal: Boon or Bane?”, The Journal of Development Studies, 49(10), 1316-1331. 